\title{
Impact of Integrated Reproductive Health Module Implementation on Junior High School Student Behavior Changes
}

\author{
Dini Saraswati Handayani, ${ }^{1,2}$ Ariyati Mandiri, ${ }^{1,2}$ Irna Kurnia Aprillanii, \\ ${ }^{1}$ Department of Public Health, Faculty of Medicine, Universitas Padjadjaran, Bandung, Indonesia, \\ ${ }^{2}$ Diploma 4 Midwifery Study Program, Faculty of Medicine, Universitas Padjajaran, Bandung, Indonesia
}

\begin{abstract}
Socio-cultural changes, low understanding of religion, development of information technology, and limitation of appropriate information sources, causes sexual and reproductive behavior problems in adolescents. The solutions are through the application of an integrated reproductive health module as a teaching guide for teachers by using student center learning approach. The objectives of this study are to analyze the implementation effect of an integrated reproductive health module on changes in student behavior. This study using a quasi-experimental pretest-posttest design with control groups, which conducted from March to May 2017. The subject in this research is the students of class VII in 5 (five) Bandung city areas by inclusion and exclusion criteria. A total of 36 students from the five junior secondary schools as the research group received an integrated learning module, while 38 students from different classes in the same school as the control group using the reproductive health module based on the 2013 Curriculum. The data collection used questionnaires to assess behavior based on self-assessment, friends, and parents. The results of this study indicate that the interpersonal communication behavior increased by $5.74 \%$, reproductive health behavior increased by $18.65 \%$, and sexual behavior increased by $9.07 \%$, with a significant difference compared to students who received the 2013 Curriculum $(\mathrm{p}<0.001)$. In conclusion, the implementation of the integrated reproductive health module had affected the student behavior change in maintaining reproductive health, sexual, and interpersonal communication.
\end{abstract}

Key words: Adolescent, behavior, integrated, reproductive health

\section{Pengaruh Penerapan Modul Pembelajaran Kesehatan Reproduksi Terintegrasi terhadap Perubahan Perilaku Siswa Sekolah Menengah Pertama}

\begin{abstract}
Abstrak
Perubahan sosial budaya, pemahaman agama yang rendah, perkembangan teknologi informasi, dan keterbatasan sumber informasi yang tepat menyebabkan permasalahan perilaku seksual dan kesehatan reproduksi pada remaja. Salah satu upaya yang dilakukan adalah melalui penerapan modul kesehatan reproduksi terintegrasi sebagai pedoman mengajar bagi guru dengan menggunakan pendekatan student center learning. Tujuan penelitian ini menganalisis pengaruh implementasi modul pembelajaran kesehatan reproduksi terintegrasi terhadap perubahan perilaku siswa. Penelitian ini menggunakan quasi-experimental pretest-posttest design with control groups yang dilakukan dari bulan Maret hingga Mei 2017. Subjek penelitian adalah siswa kelas VII di 5 (lima) wilayah Kota Bandung dengan kriteria inklusi dan eksklusi. Sebanyak 36 siswa dari lima sekolah menengah pertama sebagai kelompok perlakuan mendapatkan modul kesehatan reproduksi terintegrasi dan 38 siswa dari kelas yang berbeda di sekolah yang sama sebagai kelompok kontrol menggunakan materi kesehatan reproduksi berdasar atas Kurikulum 2013. Pengumpulan data menggunakan kuesioner penilaian perilaku oleh diri sendiri, teman, dan orangtua. Hasil menunjukkan bahwa perilaku komunikasi interpersonal siswa meningkat 5,74\%, perilaku menjaga kesehatan reproduksi meningkat 18,65\%, dan perilaku seksual sehat siswa meningkat 9,07\% dengan perbedaan yang signifikan dibanding dengan siswa yang mendapatkan Kurikulum 2013 (p<0,001). Simpulan, penerapan modul pembelajaran kesehatan reproduksi terintegrasi berpengaruh terhadap perubahan perilaku kesehatan reproduksi siswa.
\end{abstract}

Kata kunci: Kesehatan reproduksi, perilaku, remaja, terintegrasi

Received: 16 November 2017; Revised: 18 December 2019; Accepted: 23 December 2019; Published: 31 December 2019 Correspondence: Dini Saraswati Handayani, S.S.T., M.K.M. Department of Public Health, Faculty of Medicine, Universitas Padjadjaran. Jln. Prof. Eyckman No. 38, Bandung 40161, West Java, Indonesia. E-mail: d_zsharaswaty@yahoo.com 


\section{Introduction}

The behavior of adolescent reproductive health influences the quality of maternal and child health in Indonesia. ${ }^{1-3}$ Reproductive health during adolescence is one of the ways for them to pursue healthy conditions in the next future. The fulfillment of balanced nutrition can help the process of growth and development of the organs and adolescent reproductive systems.

Besides that, good personal hygiene can also prevent them from problems that will disrupt the system and their reproductive functions. So that at the time of adulthood, system and reproductive functions can work better without any problems caused by the poor behavior of maintaining reproductive health during adolescence.4.5 Besides, they are also faced with problems related to risky sexual behavior, dating at adolescence is one of the examples. ${ }^{6}$

Therefore, the education of reproductive health for children, adolescents, and young adults are needed more than just prevention of unwanted pregnancies, sexually transmitted infections, and human immunodeficiency virus. ${ }^{6}$ According to Government Regulation of the Republic of Indonesia Number 61 Year 2014, ${ }^{7}$ the services of adolescent reproductive health include communication, information and education, counseling, and medical services.

Reproductive education includes healthy life skills, mental resilience through social skills, systems, functions, and reproductive processes. It also discusses healthy and safe sexual behavior, risky sexual behavior and its consequences, family planning, and other risk behaviors or other health conditions which affect reproductive health. ${ }^{7}$

The interventions to overcome adolescent reproductive health problems are categorized based on program setting, namely, the schoolbased programs, mass media, communities, workplaces, and health facilities. ${ }^{8}$ School-based interventions, although they have a slow impact, is one of the effective efforts because it has broad coverage and directed. The results concluded that students who received education became more responsible for sexual behavior, and they were able to postpone sexual relations. ${ }^{9}$

In the national education curriculum of Indonesian, reproductive health education is not given as a separate subject but integrated into several subjects. Based on Regulation of the Minister of Education and Culture of the
Republic of Indonesia Number 24 Year 2016 ${ }^{10}$ concerning on core and essential competencies for learning in the 2013 Curriculum on primary and secondary education, it found that reproductive health materials specifically found in the Natural Sciences (Ilmu Pengetahuan Alam/IPA) and the Physical and Sports Education (Pendidikan Jasmani, Olahraga, dan Kesehatan/PJOK).

The results state that learning will be internalized and have a good impact on behavior change if it is constructed with integrated material and delivered from an early age. ${ }^{1-13}$ Integrated learning of reproductive health delivers so that students can understand the phenomenon from all sides because it is viewed from other disciplines so that they can provide insight, knowledge, and understanding in dealing with direct experienced. ${ }^{14-16}$ The integrated reproductive health education on adolescents expected to build the values, attitudes and adolescents behavior to be able to respect and protect their health and rights. ${ }^{17,18}$

The learning module of the integrated reproductive health contained material, methods, boundaries, and ways of evaluating systematically and interestingly. So, the module could help the teacher in delivering and understanding reproductive health learning material to students. Integrated reproductive health learning expected to provide an understanding of life skills, sexual and reproductive health, health behaviors and risk behaviors by integrating religious, socio-cultural and psychological by utilizing information and technological developments. ${ }^{19}$

The objectives of this study are to analyze the implementation effect of an integrated reproductive health module on changes in student behavior.

\section{Methods}

The method used in this study was the quasy experimental pretest-posttest with a group control design, which conducted from March to May 2017. In this research, there were two groups, namely the treatment and control group, which would be given a questionnaire before and after the intervention. The treatment group provided with the implementation of an integrated reproductive health learning module while the control group used reproductive health material based on the 2013 Curriculum.

The target population in this research were all junior high school at VII grader students 
of Bandung city. In contrast, the reachable population is VII grader students in 5 public junior high schools (sekolah menengah pertama negeri/SMPN), which represent each region in Bandung city. This research used five junior high schools for the treatment and control groups, namely SMPN 12, SMPN 46, SMPN 31, SMPN 27, and SMPN 24. By using simple random sampling, it is obtained 40 students as a treatment group and 40 students as the control group. However, in the implementation processes, there were 4 students drop out of the treatment group and two students in the control group.

As a result, the research subjects were 74 students divided into treatment groups (36 students) and control groups (38 students). The character of the research included gender (male and female), age (12 and 13 years), and puberty status, which was characterized by menstruation on female and nocturnal orgasm/wet dreams on males. These characteristics are directly related to the dependent and independent variables. If the effect is statistically significant, the characteristics will change to confounding variables. ${ }^{13}$

Inclusion criteria are students in the VII grade of five SMPN who attend the reproductive health learning module class, living in one house with parents, and willing to participate in the research. While the exclusion criteria are all students who have received formal education about reproductive health and if parents and friends are not willing to provide behavioral assessments.

The subject is categorized to drop out if the attendance in integrated learning activities is less than $80 \%$. The research starts with conducting an introductory survey, a literature study, and identifying the problems of reproductive health on adolescents. This module based on the results of a research of the syllabus in the 2013 Curriculum relating to reproductive health. The material of comprehensive sexuality education and the material of the great module.

In addition to the integrated reproductive health learning module that contains reproductive health material, there is also material on healthy living behavior, risky sexual behavior, and interpersonal communication that is associated with religious value, socio-cultural, and psychological. This module developed under the supervision of experts (reproductive health fields, obstetrics and gynecology/Obgyn, educational psychology, adolescent development psychology, communication, religion and socio-culture, nutrition, STIs and HIV/AIDS, and curriculum) to obtain validation, and curriculum parties of SMP of Bandung Education Office.

It is conducted the training on reproductive health learning modules by facilitators who are experts in their fields, which aim to increase the teachers' knowledge and self-efficacy about reproductive health. Afterward, the teacher implements the module for eight meetings with themes that are proper to the objectives in the module. Assessment of student reproductive health behavior conducted four times internally (herself) and externally (by parents and friends). Data analysis is used the chi-square test, paired t test, unpaired t ttest, and Mann-Whitney test.

This research was conducted after obtaining a feasibility permit from the Health Research Ethics Committee of Faculty of Medicine of Universitas Padjadjaran by applying the three basic principles of research, namely respect to person, beneficence and non-maleficence, and justice, with ethical approval letter number: 313/ UN6.C10/PN/2017.

\section{Results}

Table 1 describes the character of students generally where the chi-square statistical test found that the characteristics in both groups homogeneous ( $p>0.05)$. Homogeneity of data can be used as a benchmark to compare between treatment and control groups.

Table 1 illustrated that the characteristics of gender, age and puberty in the treatment and control group in this research have $\mathrm{p}$ value $>0.05$ so that the treatment and control groups are categorized to be homogeneous, comparable and do not result in bias.

Table 2 shows that there were statistically significant differences in the increasing score of communication behaviors before and after the intervention was given in both groups ( $p<0.05)$, and there were significant differences in the percentage of the increasing score of communication behavior on treatment (5.74\%), with $\mathrm{p}$ value $<0.05$.

Table 3 shows that there were statistically significant differences on the increasing score of reproductive health behavioral before and after intervention in both groups $(\mathrm{p}<0.05)$, and there were significant differences on the percentage of an increasing score of reproductive health behavior on intervention group (18.65\%), with $\mathrm{p}$ value $<0.05$.

Table 4 shows that there were differences 
Table 1 The Characteristic of Research Subject

\begin{tabular}{lccc}
\hline \multirow{2}{*}{ Characteristics } & \multicolumn{2}{c}{ Groups } & \multirow{2}{*}{ p Value* } \\
\cline { 2 - 3 } & Treatment (n=36) & Control (n=38) & \\
\hline Gender & 18 & 19 & 0.592 \\
$\quad$ Male & 18 & 19 & \\
$\quad$ Female & & & \\
Age (year) & 17 & 17 & 0.507 \\
$\quad 12$ & 19 & 21 & \\
$\quad 13$ & 30 & 32 & 0.583 \\
Puberty (wet dream/menstruation) & 6 & 6 & \\
$\quad$ Yes & & & \\
$\quad$ No & 16 & 18 & 0.493 \\
Having relationship & 20 & 20 & \\
$\quad$ Yes & & & \\
$\quad$ No & & &
\end{tabular}

${ }^{*}$ Chi-square test, meaningful if $\mathrm{p}<0.05$

Table 2 Comparison of Score Change in Communication Behavior Before and After the Implementation of the Integrated Reproductive Health Module

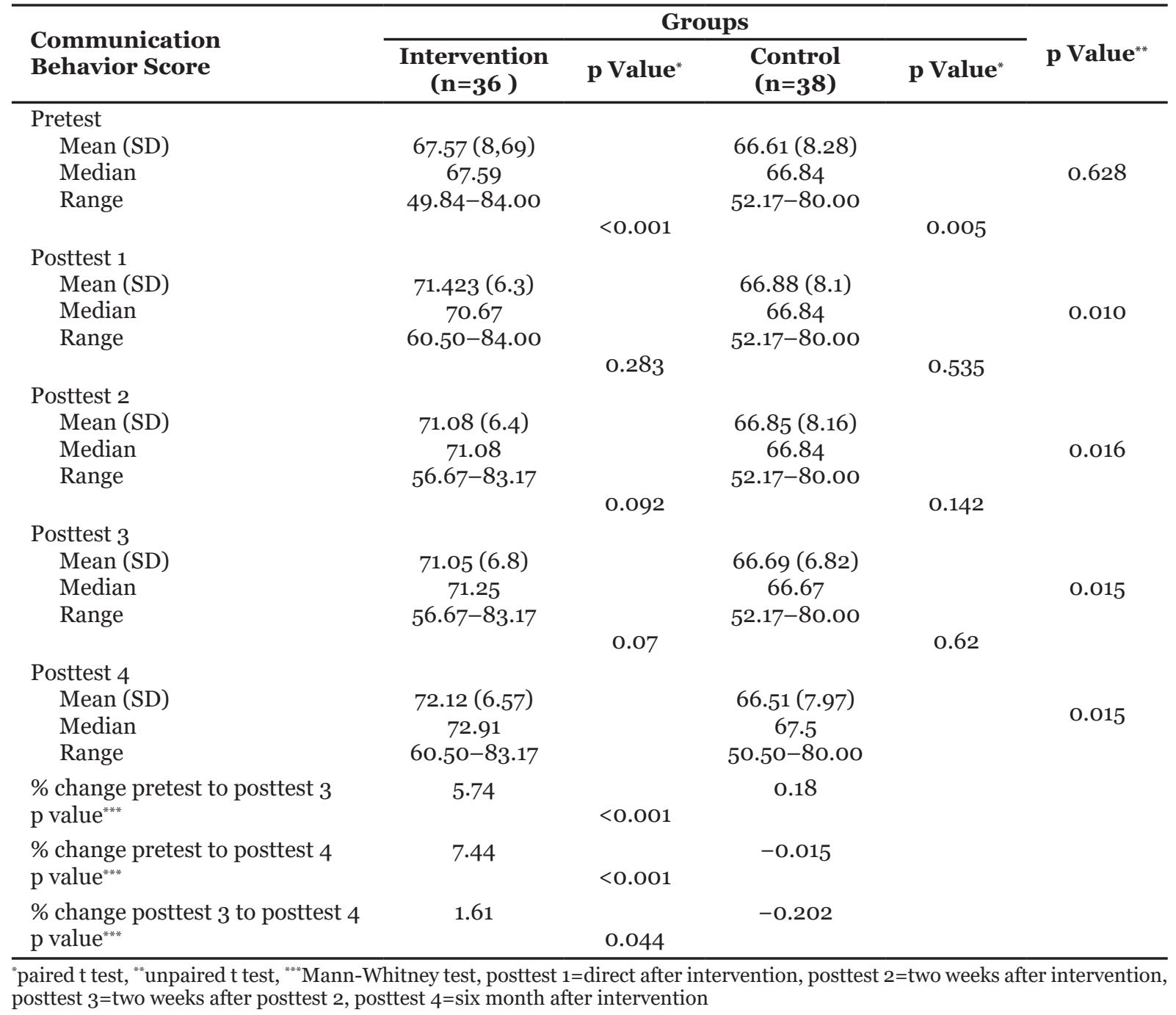


Table 3 Comparison of Score Change in Reproductive Health Behavior Before and After the Implementation of the Integrated Reproductive Health Module

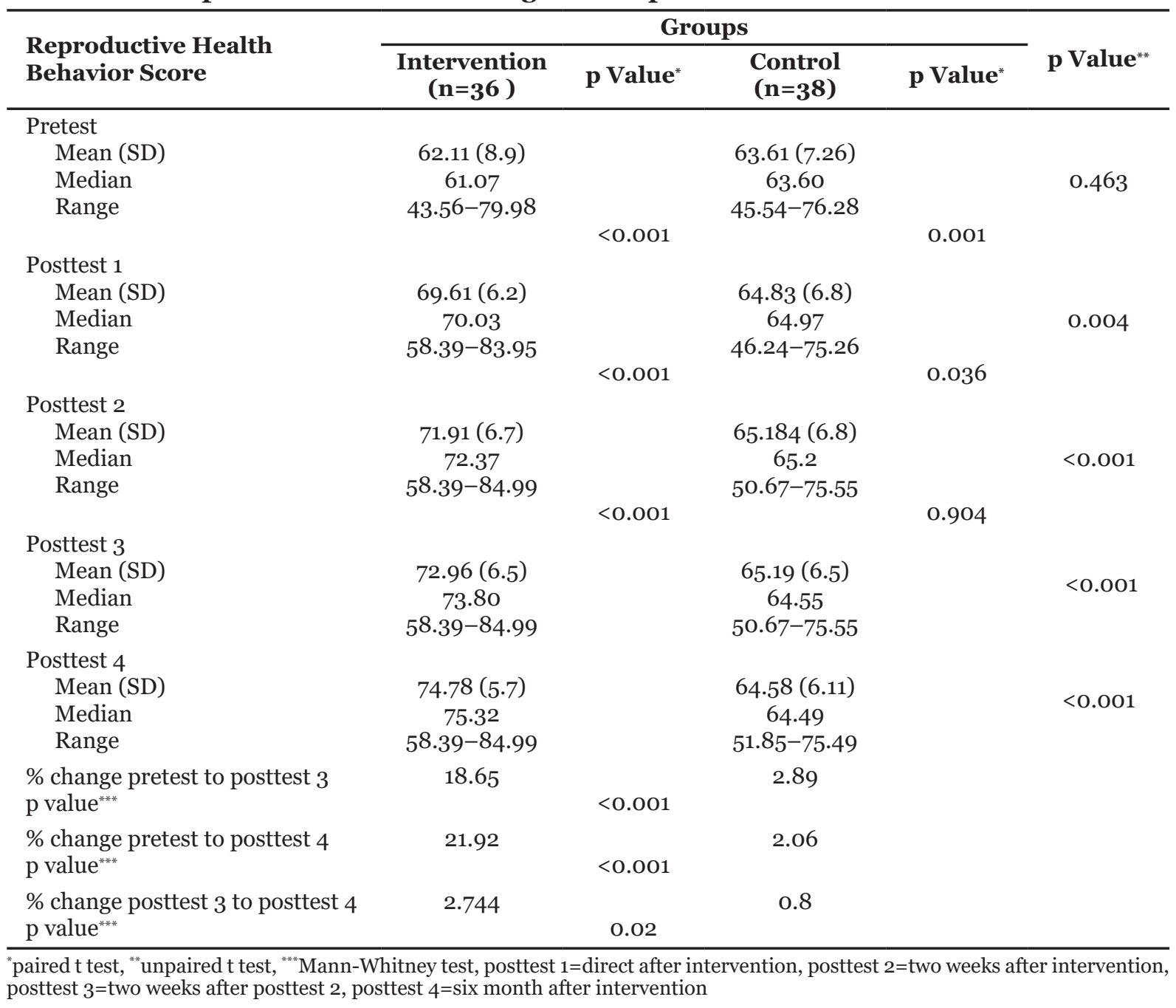

in the increased score of reproductive health behavioral scores before and after intervention in both groups ( $\mathrm{p}<0.05)$, and there were significant differences in the percentage of an increasing score of reproductive health behavior on intervention group (9.07\%), with p value $<0.05$.

\section{Discussion}

The application of integrated reproductive health learning modules that performed in this research has a significant influence on improving students' communication behavior. It is showed that the methods and material delivered by the teacher are quite capable of encouraging students to improve communication behavior. However, because communication is a behavior that must be strengthened with skills, the strengthening of communication skills material is needed to improve effective communication. ${ }^{20}$

Communication behavior is influenced by five elements of communication, according to Harold D. Lasswell. They are, for example, who? Says what? On which channel? To whom? With what effect? ${ }^{21}$ That is, to change communication behavior, it requires the involvement of many factors. Not only learning in the classroom, but the repetition and stimulus from the environment also becomes an influences factor on the changes in communication behavior.

The results of the pre and posttest on communication behavior showed a significant increase only during the intervention. However, from posttest 1 to posttest 2 and posttest 2 to 
Table 4 Comparison of Score Change in Sexual Behavior Before and After the Implementation of the Integrated Reproductive Health Module

\begin{tabular}{|c|c|c|c|c|c|}
\hline \multirow[b]{2}{*}{ Sexual Behavior Score } & \multicolumn{4}{|c|}{ Groups } & \multirow[b]{2}{*}{ p Value V $^{* *}$} \\
\hline & $\begin{array}{c}\text { Intervention } \\
\quad(n=36)\end{array}$ & p Value ${ }^{*}$ & $\begin{array}{c}\text { Control } \\
(n=38)\end{array}$ & p Value ${ }^{*}$ & \\
\hline \multicolumn{6}{|l|}{ Pretest } \\
\hline Mean (SD) & 79.38 (9.5) & & $80.04(7.8)$ & & \multirow{4}{*}{0.745} \\
\hline Median & 79.23 & & 80.87 & & \\
\hline Range & $58.23-94.40$ & & $62.58-94.93$ & & \\
\hline & & $<0.001$ & & 0.014 & \\
\hline \multicolumn{6}{|l|}{ Posttest 1} \\
\hline Mean (SD) & $84.35(6.6)$ & & $80.98(7.1)$ & & \multirow{4}{*}{0.039} \\
\hline Median & 83.89 & & 81.34 & & \\
\hline Range & $71.61-97,47$ & & $65.30-97.01$ & & \\
\hline & & $<0.001$ & & $<0.001$ & \\
\hline \multicolumn{6}{|l|}{ Posttest 2} \\
\hline Mean (SD) & $85.10(6.5)$ & & $81.37(7.1)$ & & \multirow{4}{*}{0.021} \\
\hline Median & 85.27 & & 81.74 & & \\
\hline Range & $71.61-97.39$ & & $65.97-97.01$ & & \\
\hline & & $<0.001$ & & 0.627 & \\
\hline \multicolumn{6}{|l|}{ Posttest 3} \\
\hline Mean (SD) & $85.97(6.3)$ & & $81.44(7.0)$ & & \multirow{4}{*}{0.005} \\
\hline Median & 86.05 & & 81.76 & & \\
\hline Range & $72.92-97.39$ & & $66.61-97.39$ & & \\
\hline & & 0.033 & & 0.012 & \\
\hline \multicolumn{6}{|l|}{ Posttest 4} \\
\hline Mean (SD) & $87.12(5.3)$ & & $80.76(6.8)$ & & \multirow{3}{*}{$<0.001$} \\
\hline Median & 86.85 & & 80.81 & & \\
\hline Range & $72.92-97.39$ & & $66.61-93.58$ & & \\
\hline $\begin{array}{l}\text { \% change pretest to posttest } 3 \\
\text { p value } \text { v }^{* * *}\end{array}$ & 9.07 & $<0.001$ & 1.94 & & \\
\hline $\begin{array}{l}\text { \% change pretest to posttest } 4 \\
\text { p value }\end{array}$ & 10.78 & $<0.001$ & 1.12 & & \\
\hline $\begin{array}{l}\text { \% change posttest } 3 \text { to posttest } 4 \\
\text { p value }{ }^{* * * *}\end{array}$ & 9.07 & 0.002 & 1.94 & & \\
\hline
\end{tabular}

"paired t test, ${ }^{* *}$ unpaired t test, ${ }^{* * *}$ Mann-Whitney test, posttest 1=direct after intervention, posttest 2=two weeks after intervention, posttest $3=$ two weeks after posttest 2 , posttest $4=$ six month after intervention

posttest 3 , both in the intervention and control group, their increases were not significant. Moreover, there was a decrease in the average score on communication behavior from posttest 2 to posttest 3 in the control group. In line with the theory, which states that skills strongly influence communication. ${ }^{20}$ Although the difference in the percentage score gets a significant value in the treatment group, the value is lower when compared with the percentage of an increasing score of reproductive health behavior.

The results of in-depth interviews through focus group discussion (FGD) on parents and friends found that if compare to the material of reproductive health and sexuality, communication materials are a little more challenging to understand because it has not enough to explain only by the theory. Students who have shy characters will have little difficulty in performing the practices implemented in the communication theme learning.

However, according to several FGD participants, the game of Johari Window from the module provides a new experience to give and get ratings from friends, so they can be more open and understand themselves. On changes in reproductive health, this research provides significant results. It shows that the methods and material presented by the teacher can encourage students to reproduce better health behavior. 
The main factor that underlying the formation of changes in reproductive health behavior is the provision of detail information and delivery of the right methods in the classroom.

During the implementation process, the teacher has been provided with core and supporting material by experts. At the time of implementation takes place, the teacher already has the knowledge and functional selfefficacy. In addition to understanding social and cultural-religious values and adolescent psychology becomes a strengthening factor in the presentation of material in the class.

At pretest time, students have inadequate knowledge and attitudes towards reproductive health behaviors, so that it can influence the behavior. Submitting the dangers of poor reproductive health behavior and explicit material on how to perform these behaviors makes students have better knowledge and attitudes at the end of learning, so they try to do these behaviors in their daily lives.

At the time after the implementation of the change in behavior exists, the value is not as significant as when the assessment conducted one month later. Behavior is a response to a stimulant that must be done repeatedly and is influenced by internal and external factors, so the assessment of 4-week, 8-week, and 6-month continue to very good improvement.

It is in line with the theory of models which developed to illustrate and explain that behavior change requires certain stages. This model is based on the statement that behavior change is a process, not an event and that individuals have varying degrees of motivation or readiness to change the behavior. ${ }^{22}$ Reproductive health behavior in students after implementation is in the contemplation phase. It is where a person begins to respond to make changes to certain behaviors. One month later, students enter the preparation and action phase. It is where students have begun to make serious commitments to change and behavior. Then to make sure the behavior changes to the character, it will take six months or called by the maintenance phase. ${ }^{23}$

During the intervention, they only get an explanation of the nutrition fulfillment of adolescents, personal hygiene, and risky sexual behavior delivered by the lecture method in most schools.

In line with reproductive health behavior, the low of sexual behavior on adolescents often caused by ignorance of the impact that will occur. ${ }^{24}$ For sexual behavior, the influence of external factors is more significant when compared to the behavior of maintaining reproductive health..$^{25}$

By knowing the impact, students become more afraid to perform risky sexual behavior. Besides, the method of interactive presentation and student involvement will make them more understanding, not just only knowing. For the control group who did not get the module, they also experienced increasing scores on sexual behavior during the intervention (pretest to posttest 1). Besides that, the repeated questions in the questionnaire become a source of information for students to conduct good sexual behavior. However, this researcher cannot control the interactions between students in the control and the intervention group, so information exchange between the groups is likely to occur. In both groups, the score of the beginning assessment of sexual behavior before the intervention was good. It was because of the age of the respondents were still early adolescents and was still little influence from external factors that influenced sexual behavior. Therefore sexual health material can be used as a prevention effort, so when adolescence grows up, they have the self-concept and strong beliefs to avoid risky sexual behavior.

By using the Spearman rank correlation test between the three dependent variables, there is a significant relationship between them $(\mathrm{p}<0.05)$. Thus, it can be said that communication behavior, reproductive health, and sexual behavior have links with one to another. To achieve optimal reproductive and sexual health during adolescence to adulthood phase needs good behavior in communication, maintains reproductive health, and avoids risky behavior.

\section{Conclusions}

Implementation of the integrated reproductive health module had affected changes in students' reproductive health behavior.

\section{Conflict of Interest}

The authors have no conflict of interest to report.

\section{Acknowledgments}

Our thanks to teachers and students in five public junior high schools who participated 
in this study. To all the experts who helped us solve the problems, Bandung City Department of Education, who gave research permission and especially to Universitas Padjadjaran for funding the research through an internal grant.

\section{References}

1. Fatmawati I. Perbandingan tingkat pengetahuan dan sikap remaja yang mendapat program DAKU! dan yang tidak terhadap kesehatan reproduksi remaja di Kota Singkawang [undergraduate thesis]. Depok: Fakultas Kesehatan Masyarakat, Universitas Indonesia; 2012 [cited 2017 February 20]. Available from: http://lib. ui.ac.id/file? file $=$ digital $/ 20320038-S-$ Ima\%20Fatmawati.pdf.

2. Ramayanty D, Sanusi SR, Fitria M. Hubungan pengetahuan dan sikap remaja tentang kesehatan reproduksi dengan perilaku seksual di SMA Bayu Pertiwi Sunggal tahun 2015. GKRE. 2015;1(2):4553.

3. Farhanah, Ibrahim R, Ridwan R. Proceeding report: comperhensive sexuality education fair 2015 [Internet]. Jakarta: Rutgers WPF Indonesia; 2015 [cited 2017 February 20]. Available from: https://www.researchgate. net/publication/308103997_Proceeding report_Comprehensive_Sexuality_ Education_Fair_2015.

4. Ayu M, Rosmawar C. Hubungan pengetahuan dan sikap dengan perilaku kesehatan reproduksi pada remaja putri di SMA 5 Banda Aceh [undergraduate thesis]. Banda Aceh: STIKes U'Budiyah; 2013 [cited 2017 February 20]. Available from: https://adoc. tips/hubungan-pengetahuan-dan-sikapdengan-perilaku-kesehatan-rep.html.

5. United Nations Educational, Scientific and Cultural Organization (UNESCO). Puberty education \& menstrual hygiene management. Paris: UNESCO; 2014.

6. Hurlock EB, Istiwidayanti, Soedjarwo, Sijabat RM. Psikologi perkembangan: suatu pendekatan sepanjang rentang kehidupan. $5^{\text {th }}$ Edition. Jakarta: Penerbit Erlangga; 1991.

7. Peraturan Pemerintah Republik Indonesia Nomor 61 Tahun 2014 tentang Kesehatan Reproduksi.

8. Speizer IS, Magnani RJ, Colvin CE. The effectiveness of adolescent reproductive health interventions in developing countries: a review of the evidence. J Adolesc Health. 2003;33(5):324-48.

9. Peraturan Menteri Pendidikan dan Kebudayaan Republik Indonesia Nomor 24 Tahun 2016 tentang Kompetensi Inti dan Kompetensi Dasar Pelajaran pada Kurikulum 2013 pada Pendidikan Dasar dan Pendidikan Menengah.

10. Breuner CC, Mattson G, AAP Committee on Adolescence, AAP Committee on Psychosocial Aspects of Child and Family Health. Sexuality education for children and adolescents. Pediatrics. 2016;138(2):e20161348.

11. Lally P, van Jaarsveld CHM, Potts HWW, Wardle J. How are habits formed: modelling habit formation in the real world. Eur J Soc Psychol. 2010;40(6):998-1009.

12. Creswell JW, Fawaid A, Pancasari RK. Research design: pendekatan metode kualitatif, kuantitatif, dan campuran. $4^{\text {th }}$ Edition. Yogyakarta: Pustaka Pelajar; 2016.

13. Sastroasmoro S, Ismael S. Dasar-dasar metodologi penelitian klinis. $5^{\text {th }}$ Edition. Jakarta: Sagung Seto; 2014.

14. International Youth Foundation. Integrating reproductive health into youth development programs: lessons for the future [Internet]. Field Notes. Volume 4. Number 18. December 2011 [cited 2017 March 30]. Available from: https://www.iyfnet.org/sites/default/files/ FieldNotes18_Integrating_Reproductive_ Health.pdf.

15. Wahba M, Roudi-Fahmi F. The need for reproductive health education in schools in Egypt [Internet]. Population Reference Bureau (PRB) Policy Brief. October 2012 [cited 2017 April 22]. Available from: https:// www.prb.org/wp-content/uploads/2012/10/ reproductivehealth-education-egypt.pdf.

16. United Nations Educational, Scientific and Cultural Organization (UNESCO). Emerging evidence, lessons and practice in comprehensive sexuality education: a global review. Paris: UNESCO; 2015.

17. World Health Organization (WHO). A standards-driven approach to improve the quality of health-care services for adolescents: policy brief [Internet]. Geneva: WHO; 2015 [cited 2017 April 30]. Available from: https:// apps.who.int/iris/handle/10665/184035.

18. United Nations Population Fund (UNFPA). The evaluation of comprehensive sexuality education programmes: a focus on the 
gender and empowerment outcomes [Internet]. New York: UNFPA; 2015 [cited 2017 April 31]. Available from: https:// www.unfpa.org/sites/default/files/pub-pdf/ UNFPAEvaluationWEB4.pdf.

19. Aarø LE, Flisher AJ, Kaaya S, Onya H, Fuglesang M, Klepp KI, et al. Promoting sexual and reproductive health in early adolescence in South Africa and Tanzania: development of a theory- and evidence-based intervention programme. Scand J Public Health. 2006;34(2):150-8.

20. Zoppi K, Epstein RM. Is communication a skill? Communication behaviors and being in relation. Fam Med. 2002 May;34(5):319-24.

21. Syam NW. Psikologi sebagai akar ilmu komunikasi. Bandung: Simbiosa Rekatama Media; 2011.

22. Fishbein M, Ajzen I. Predicting and changing behaviour: the reasoned action approach.
New York: Psychology Press; 2010.

23. Parmar SM, Taylor R. Health promotion \& behavioural change theory [Internet]. Calgary, Canada: Alberta Health Services; 2010 [cited 2017 April 29]. Available from: https://pdf4pro.com/cdn/healthpromotion-amp-behavioural-change-theory2d602.pdf.

24. World Health Organization (WHO). Developing sexual health programmes: a framework for action [Internet]. 2010 [cited 2017 May 10]. Available from: https://apps.who.int/iris/bitstream/ handle/10665/70501/WHO_RHR_ HRP_10.22_eng.pdf.

25. McCall D, McKay A; Society of Obstetricians and Gynaecologists of Canada. School-based and school-linked sexual health education and promotion in Canada. J Obstet Gynaecol Can. 2004;26(6):596-605. 